\title{
Substrate characteristics affect colonization by the bloom-forming diatom Didymosphenia geminata
}

\author{
Elizabeth A. Bergey $\cdot$ Joshua T. Cooper • \\ Barret C. Phillips
}

Received: 12 December 2008/Accepted: 24 April 2009/Published online: 6 May 2009

(C) The Author(s) 2009. This article is published with open access at Springerlink.com

\begin{abstract}
The long-stalked Didymosphenia is capable of forming large blooms and is expanding its range. To better understand the colonization dynamics of this species, we investigated the role of substrate characteristics-rock roughness and biofilm condition-on Didymosphenia colonization in a montane Colorado stream. Rocks differing in roughness (shale and sandstone) were treated to manipulate the diatomdominated biofilm by scrubbing or submersion in $30 \%$ hydrogen peroxide. Initial chlorophyll concentration differed among rock types (sandstone $>$ shale) and biofilm treatments (untreated $>$ scrubbed $>$ hydrogen peroxide-treated). Rocks were placed in a Didymosphenia bloom area for 8 days. More Didymosphenia colonized the rougher sandstone than the smoother shale, and more colonized stones with intact biofilms than stones with reduced biofilms (intact $>$ scrubbed $>$ hydrogen peroxide). These results suggest that rougher stones may be targeted for surveillance for new populations and that the colonization of intact
\end{abstract}

E. A. Bergey $(\square)$. J. T. Cooper · B. C. Phillips Oklahoma Biological Survey, University of Oklahoma, Norman, OK 73019, USA

e-mail: lbergey@ou.edu

E. A. Bergey · B. C. Phillips

Department of Zoology, University of Oklahoma, Norman, OK 73019, USA

J. T. Cooper

Department of Botany and Microbiology, University of Oklahoma, Norman, OK 73019, USA biofilms is consistent with Didymosphenia's habitat in regulated rivers, where biofilm-scouring spates may be suppressed.

Keywords Invasive species - Diatom colonization Substrate texture $\cdot$ Periphyton $\cdot$ Rock substrata

\section{Introduction}

Didymosphenia geminata (Lyngbye) Schmidt has the notoriety of being the only invasive diatom species with potentially large ecological (Larned et al. 2007) and economic (Branson 2006) effects. This species was historically reported in low numbers in several rivers in the northern hemisphere. In the last several years, however, reports of nuisance blooms have become regionally common, and populations have appeared at new sites within this range (reviewed by Spaulding and Elwell 2007) and have occurred under more varied environmental conditions (Kawecka and Sanecki 2003; Bhatt et al. 2008). Additionally, Didymosphenia has established large populations in several rivers in the South Island of New Zealand since its discovery in 2004 (Kilroy 2004), despite containment strategies.

Didymosphenia is a relatively large diatom that occurs as colonies of cells on long branching stalks. Colonies are initially small tufts, and as the 
population grows, these tufts can grow and coalesce into mats. In some blooms, mats cover much of the streambed and, in New Zealand, mats may be several centimeters thick (Kilroy et al. 2005). Mats, composed primarily of stalks (Larned et al. 2007), may accumulate fine sediments and persist longer than the diatoms that made them (Kirkwood et al. 2007; Spaulding and Elwell 2007). Ecological studies of Didymosphenia blooms are ongoing, with the majority of research centering on the extensive, invasive growths in New Zealand (e.g., Kilroy et al. 2005; Larned et al. 2007). Such studies have examined associations with discharge and water chemistry, effects of floods, nutrient limitation, effects on invertebrate and fish assemblages and on water chemistry. Using information on habitat preferences and river characteristics, Kilroy et al. (2008) predicted the potential geographical range of Didymosphenia within New Zealand rivers.

There has been a paucity of research on early colonization dynamics of diatoms, including Didymosphenia. Specifically, the role of substrate characteristics in initial settlement of diatoms and other streambed algae has been little explored, although crevices have been implicated as selective settlement sites by motile zoospores of the filamentous green alga Cladophora glomerata (Dudley and D'Antonio 1991). In contrast, surface roughness is recognized as an important determinant in the settlement of many species of marine invertebrates and macroalgae on hard surfaces.

Settling diatoms are only one component of benthic stream biofilms, which also include organic compounds and detritus, and bacteria and other microbial organisms. Developing biofilms may obscure substrate characteristics, including textural features, of underlying surfaces. For example, Blinn et al. (1980) found differences in algal colonization among three rock types after the first week of colonization, but this difference disappeared after the second week because of changes in surface characteristics as biofilms and organic matter accumulated.

Our objective was to test whether substrate characteristics (i.e., rock roughness and biofilm presence) affected settlement and early establishment by Didymosphenia geminata. This was accomplished by means of a field experiment in which rough sandstone and smooth shale rocks with intact or modified biofilms were introduced into a section of the East River during a nuisance bloom of Didymosphenia, and colonization of Didymosphenia on these rocks was evaluated after a colonization period of 8 days.

\section{Materials and methods}

Research sites were located in the upper East River (Gunnison County, Colorado), where it is a secondorder unimpounded montane stream within the Gunnison National Forest. The stream meanders through a glacial valley and has a wide riparian zone of short willows. The field experiment was conducted within the town of Gothic (location of the Rocky Mountain Biological Laboratory) at an elevation of 2,900 $\mathrm{m}$. Here, the stream remains meandering, but the higher banks support riparian conifers (Fig. 1).

The geological diversity of the watershed (Gaskill et al. 1991) results in a diversity of igneous, sedimentary, and meta-sedimentary rocks in the streambed, which contains at least ten types of rock throughout the areas used in this study. The smoothest rock type in the streambed is Mancos shale and the roughest is red-sandstone of the Maroon formation (Bergey, unpublished data).

The diatom Didymosphenia geminata formed dense small mats in parts of the East River during summer 2007. Mats resembled coalescing tufts of dirty cotton and were easily visible in the stream. Didymosphenia

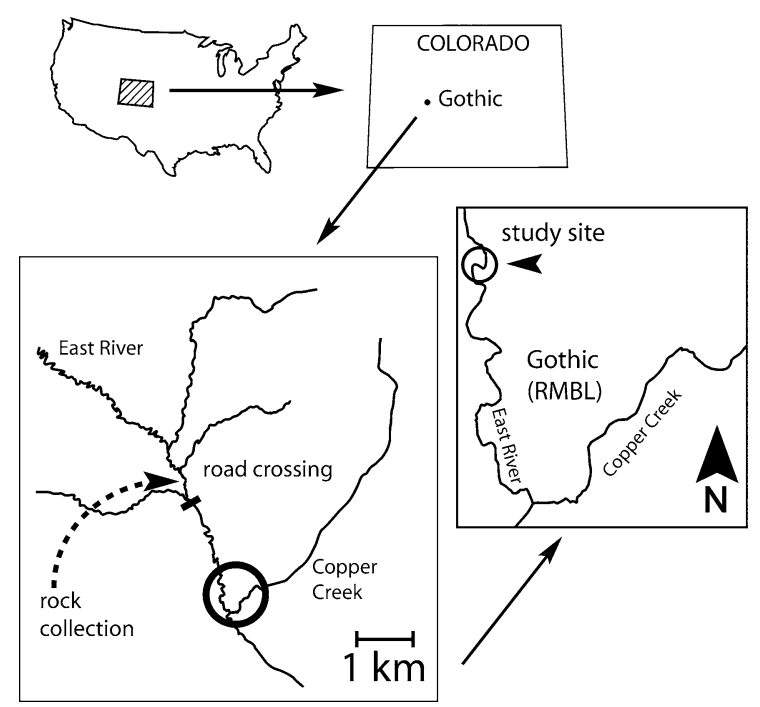

Fig. 1 Map of locations of the East River study sites-both the upstream rock collection area and the downstream field experiment site 
mats were common in the section of the East River that passes through Gothic, but had not been found much further upstream. Ongoing surveys had failed to find Didymosphenia above the Gothic Road crossing on the East River, $2 \mathrm{~km}$ upstream of Gothic (Brad Taylor, unpublished data). Fifty-four river-smoothed shale and 54 river-smoothed sandstone rocks were collected from two adjacent riffles about a half kilometer upstream of the Gothic Road crossing, where Didymosphenia did not yet occur. The underside of rocks was marked using a wax crayon to show orientation, and rocks were stacked in ice chests and taken to the downstream experimental site.

Two-thirds of the rocks were processed to alter the biofilm. Eighteen shale and eighteen sandstone rocks were vigorously scrubbed with a brush and an equal number of rocks were placed in 30\% hydrogen peroxide for $5 \mathrm{~min}$. Processed rocks were soaked in stream water, bagged, and put in coolers.

Directly after biofilm treatment, rocks were placed in shallow water along the outer bend of a meander of the East River within Gothic, where most streambed rocks had numerous visible tufts of Didymosphenia colonies. The upper set was in an area of coarse sand; the lower set was in an area of mixed coarse sand and cobbles, some of which were emergent. Six replicates of each rock type (shale and sandstone) and biofilm treatment (untreated biofilm, scrubbed, and $\mathrm{H}_{2} \mathrm{O}_{2^{-}}$ treated) were placed in the upstream set and six replicates were placed in the downstream set; the marked undersides were used to prevent rocks from being placed upside-down. Treatments were assigned randomly within each set. Six replicates of each stone type-biofilm treatment were returned to the lab and refrigerated prior to chlorophyll analysis, which was started a couple of hours later.

Rocks were placed in the East River on 1 August 2007 and were retrieved and placed in labeled bags 8 days later on 9 August. During retrieval, rocks were lifted carefully to minimize loss of loosely adhered material. Rocks were stored frozen. During processing, rocks were placed in open-top vacuum-seal bags with $25-50 \mathrm{ml}$ of $30 \%$ hydrogen peroxide and heated in a $78^{\circ} \mathrm{C}$ water bath until effervescence stopped in 15-20 min. Bags were shaken and the liquid poured into glass settling chambers. Samples were rinsed by settling and decanting to remove hydrogen peroxide and the final liquid volume was adjusted to $15 \mathrm{ml}$. Subsamples of $0.15 \mathrm{ml}$ were dried onto coverslips and mounted on microscope slides with Naphrax mounting medium (Northern Biological Supply, Ipswich, UK). Slides were labeled only by their sample number, on the basis of the random location in the field experiment; hence, the rock type and treatment were not known during diatom counting. Slides were viewed at $200 \times$ with DIC, using a Leica DMLB microscope (Leica Microsystems, Wetzlar, Germany). All Didymosphenia valves were counted on the slide and numbers were converted to number of valves per square centimeter of rock using each rock's surface area. The planar area of each rock was obtained by weighing prints of scanned rocks and using the printer paper's mass-area relationship (as in Bergey and Getty 2006).

Rocks reserved at the start of the experiment were analyzed for chlorophyll $a$ concentration, as an indicator of biofilm removal by the scrubbing and hydrogen peroxide treatments. An ethanol extraction technique was used (Sartory and Grobbelaar 1984). To prevent loss of ethanol during whole-rock extraction, individual rocks and $50 \mathrm{ml}$ of ethanol were sealed in vacuum-seal bags. Absorbances were measured with a Beckman Coulter DU530 spectrophotometer (Beckman Coulter, Inc., Fullerton, California, USA).

Rock roughness was measured for the sandstone and shale rocks used in the experiment, using the method of Bergey (2006). Briefly, this method entailed finding the ratio of two surface area measurements - an idealized surface area based on the length, width, and height measurements and a more accurate surface area based on the weight gain when the rock was wetted with a soap solution. The resulting roughness value is dimensionless. Twenty rocks of each type were measured.

Data analysis

Because rock size was variable, potential relationships of (1) rock area and chlorophyll $a$ concentration of the initial rocks and (2) rock area and Didymosphenia density of the experimental rocks were tested using linear regression. Rock roughness was compared between sandstone and shale using an unpaired $t$-test.

Potential differences in chlorophyll concentration and in Didymosphenia density among rock types and biofilm treatments were each tested with three-way ANOVAs (rock type or chlorophyll concentration, 


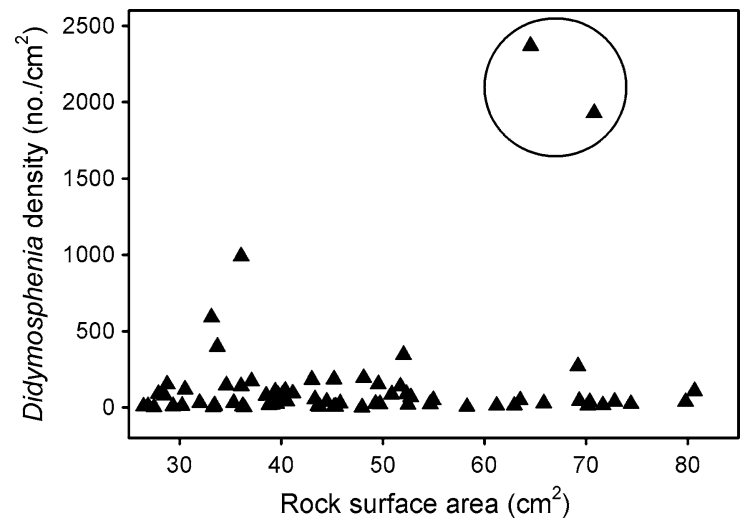

Fig. 2 Regression between the rock size of hydrogen peroxide treated rocks and Didymosphenia geminata density after 8 days colonization in the East River. Two outlying data points are circled

biofilm treatment, and experiment location), followed by Tukey's multiple comparison tests to distinguish differing means. Experiment location was included in the ANOVAs because differing local hydraulic conditions, indicated by different stream substrates, may affect settlement of Didymosphenia. To better meet the assumptions of ANOVA, data were squareroot transformed prior to analyses. For clarity, all graphs show non-transformed data.

The Didymosphenia density dataset included two outliers with counts of 4.8 and 6.0 standard deviations from the mean (Fig. 2). Because of the large effect of these outliers on the ANOVA, these two data points were removed from the formal statistical analysis but were then discussed relative to the ANOVA results.

\section{Results}

Because rock size can affect chlorophyll concentration and possibly Didymosphenia settlement, rock size was compared among sets of rocks. Rock size ranged between 24.9 and $80.7 \mathrm{~cm}^{2}$. There was no significant difference in rock size between shale and sandstone [mean (SE) 44.7 (12.4) and $45.5(14.5) \mathrm{cm}^{2}$, respectively; $t=-0.37, P=0.71 ; N=54$ ], nor between initial and experimental stones [mean $(\mathrm{SE})=42.3$ (1.9) and 46.6 (1.7), $N=36$ and 72, respectively; $t=-1.50, \quad P=0.14]$. Among the experimental stones, rock size did not differ between the two locations or between shale and sandstone, but differences occurred among the biofilm treatments (ANOVA; $P=0.25,0.21$, and 0.002 ; respectively). Hydrogen peroxide stones were larger than scrubbed stones [mean (SE) $=53.9$ (2.9) and 40.7 (2.1]; Tukey's test $P<0.05$ ). To test whether stone size affected Didymosphenia settlement, Didymosphenia density was regressed against the rock size of hydrogen peroxide-treated rocks, which had the highest size range (26.5-72.8 $\mathrm{cm}^{2}$; Fig. 2). Rock size was not related to Didymosphenia colonization density (regression $R^{2}=0.094$; ANOVA, $F=2.27, P=0.15$ ).

Sandstone rocks used in the experiment were much rougher than the shale rocks ( $t$-test: $t=6.895$, $P<0.0001)$. Sandstone roughness averaged 3.25 $(\mathrm{SE}=0.34)$, whereas shale averaged 0.77 ( $\mathrm{SE}=$ $0.05)$.

Chlorophyll $a$ analysis showed that the biofilm treatments at the beginning of the experiment did, indeed, affect the biofilm (Fig. 3). Overall, sandstone had higher chlorophyll concentration than did shale [mean (SE) $=29.5$ (4.0) and 7.4 (1.7) $\mathrm{mg} \mathrm{m}^{-2}$, respectively; ANOVA, $F=29.76, P<0.0001]$ and this difference was consistent across biofilm treatments. The intact biofilm (no treatment) had the highest chlorophyll biomass, which was significantly different from the hydrogen peroxide-treated rocks, which had the lowest biomass (Tukey's test, $P<0.05)$. Scrubbing the rocks produced an intermediate chlorophyll biomass. Field observations were consistent with these results-both scrubbing and hydrogen peroxide treatment removed the slimy

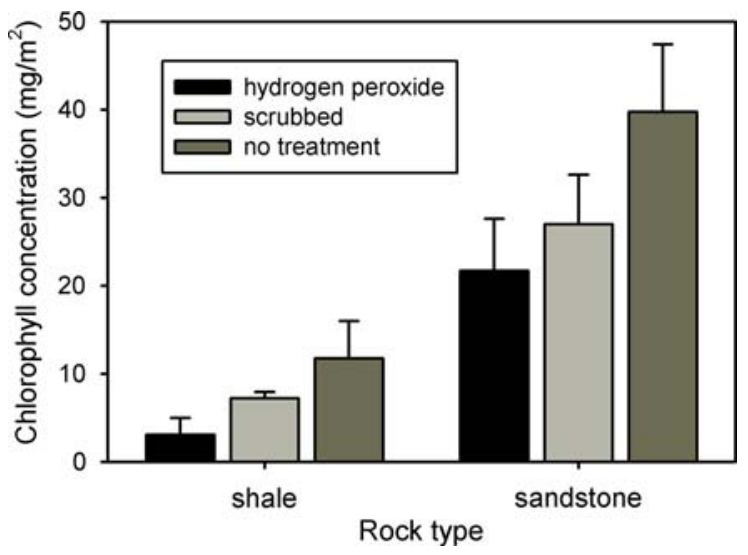

Fig. 3 Chlorophyll $a$ concentration (used to indicate biofilm quantity) of transplanted streambed rocks at the start at the colonization experiment. Hydrogen peroxide and scrubbing were used to reduce biofilm. Bars are $+1 \mathrm{SE}$ 


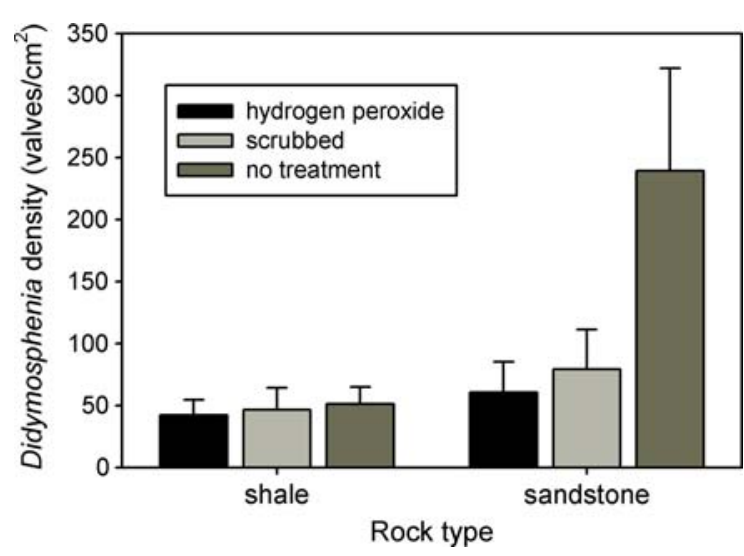

Fig. 4 Didymosphenia colonization, as density of valves, on rocks after 8 days exposure in a section of river with a moderate Didymosphenia bloom. Two types of rock (shale and sandstone) and three biofilms treatments (no treatment, scrubbed rocks, and rocks treated with hydrogen peroxide) were tested. Bars are $+1 \mathrm{SE}$

brownish coating remaining on rocks with untreated biofilms.

Substrate colonization by Didymosphenia differed between shale and sandstone, and among the biofilm treatments (Fig. 4). Sandstone accrued more Didymosphenia than did shale [means $(\mathrm{SE})=130.3$ (34.2) and 47.8 (8.3) cells $\mathrm{cm}^{-2}$, respectively; $F=5.93$, $P=0.018]$. The intact biofilm accrued more Didymosphenia than did either of the treatments that reduced the biofilm [mean $(\mathrm{SE})=145.4$ (45.3), 63.0 (18.3), 50.7 (13.0]; respectively, for no treatment, scrubbed, and hydrogen peroxide treatments; $F=$ 3.30, $P=0.044)$. Didymosphenia colonization did not differ between the upstream and downstream sets of rocks $(F=0.61, P=0.44)$.

The two outlier data points occurred in the hydrogen peroxide-treated sandstone. Didymosphenia densities were 2,369 and 1,929 per $\mathrm{cm}^{2}$, compared with a mean of 87.4 valves per $\mathrm{cm}^{2}$ in the other 70 rocks. Small tufts of Didymosphenia were noticed on a couple of sandstone rocks at the end of the experiment, and it was likely in the high-density rocks.

\section{Discussion}

Didymosphenia colonization differed between the rougher sandstone and the smoother shale, with many more colonizers on sandstone, the rougher surface. This pattern was also noted in streams near Gothic, where visible colonies were first seen on sandstone. Likewise Blinn et al. (1980) found more diatom biomass on sandstone than on basalt or limestone after a comparable colonization period and attributed the difference to stone roughness and/or solubility. A subsequent experiment on the role of rock chemistry on algal colonization (Bergey 2008) showed that rock chemistry had little effect. Unfortunately, rock type is seldom reported in habitat descriptions, making larger scale evaluation of the importance of rock type and rock roughness difficult.

Because Didymosphenia forms colonies, colonization may occur by settlement of individual cells or by colony fragments. The density of colonizing Didymosphenia on our rock substrates was highly variable. Two of the 72 rocks had about 2,000 valves $\mathrm{cm}^{-2}$, in contrast to the rest of the rocks, which averaged about 90 valves $\mathrm{cm}^{-2}$, which may indicate colonization by colony fragments on the two high-density rocks. Although in situ production contributes to biomass increase after settlement starts (Peterson 1996), it is unlikely that the short 8-day colonization period would produce such high densities on only two rocks if colonization occurred as single cells. Indeed, the two high-density rocks were the roughest combination (sandstone treated with hydrogen peroxide, which reduced the biofilm and increased direct rock surface exposure) and colony fragments may have snagged on these rocks. Both single cells and colony fragments occur in the drift during blooms (cells: Kilroy et al. 2005; fragments: Cathy Kilroy, personal communication 2008); therefore, both can settle on streambed substrates.

Rock size can affect algal biomass, but was not a factor in this experiment. The sandstone and shale rocks had a similar range of rock size and no correlation was found between rock size and Didymosphenia density. Similarly Kilroy et al. (2005) found rock size unrelated to Didymosphenia density during blooms in New Zealand.

Didymosphenia colonization was greater on intact diatom-dominated biofilms than on disrupted biofilms, which is consistent with the general colonization pattern of biofilms on submerged surfaces. Diatoms are generally not the first colonizers of bare surfaces in streams; rather a microbial and organic layer first forms (Barranguet et al. 2005), followed by colonization of adnate and short-stature diatoms (Hudon and Bourget 1981). Thus, Peterson and Stevenson (1989) and Sekar 
et al. (2004) found that diatoms colonized non-algal biofilms faster than cleaned substrates. Following this initial diatom assemblage, stalked and branched colonies become more abundant (Hudon and Bourget 1981; Hoagland et al. 1982; Ács et al. 2000), which was observed in this study by the greater colonization of Didymosphenia on intact biofilms. Korte and Blinn (1983) found that upright diatoms, including those with stalks, become abundant on introduced substrates after 2 weeks in riffles-a longer colonization period than used in our study.

Rock roughness may interact with biofilm development and indirectly affect Didymosphenia colonization. During colonization, rougher substrates accrue greater biofilm biomass than smoother substrates (Blinn et al. 1980; Clifford et al. 1992). By promoting biofilm development, the rougher sandstone may be more conducive to Didymosphenia colonization than the smoother shale.

Sites with invasive or nuisance Didymosphenia blooms are typically rivers that are regulated, occur below lakes, or have low variation in flow (e.g., Kawecka and Sanecki 2003; Kirkwood et al. 2007; Beltrami et al. 2008), where the biofilm is little disturbed by rain-associated spates. This study indicates that habitat conditions in these rivers may promote Didymosphenia establishment by maintaining a biofilm suitable for Didymosphenia colonization.

The apparent selection of surface traits by settling Didymosphenia (e.g., sandstone $>$ shale and intact biofilm $>$ reduced biofilm) implies the possibility that diatoms can select surfaces. Once individual diatoms reach a surface, adhesion, movement, and release are active processes (Cooksey and Wigglesworth-Cooksey 1995; Wetherbee et al. 1998) that could allow substrate selection. Studies using marine diatoms have demonstrated responses to physical and chemical cues (Wigglesworth-Cooksey and Cooksey 1992; Falciatore et al. 2000; Thompson et al. 2008) and such cues may be involved in diatom colonization. Texture characteristics are a factor-more diatoms settle on rougher artificial substrates than on smoother substrates (Sekar et al. 2004; Patil and Anil 2005), and this study demonstrated greater colonization of the rougher sandstone than the smoother shale.

Because Didymosphenia geminata colonized rougher rocks with intact biofilms, the use of introduced artificial substrates (especially smooth substrates like glazed tiles) in survey or surveillance programs is not appropriate. Instead, surveillance programs should target rougher in situ rocks.

\section{Conclusions}

1. Didymosphenia geminata colonized the rough rocks (sandstone) faster than the smooth rocks (shale). This experimental result was consistent with field observations and indicates that surveillance programs for this species might target the rougher rock types. There is a paucity of information on rock type and roughness in studies of Didymosphenia and this information might prove useful in better understanding the species' distribution.

2. Rock size, within the range of large gravel to cobble, did not affect colonization by Didymosphenia.

3. Didymosphenia colonized rocks with intact biofilms faster than rocks with disrupted biofilms. This pattern is consistent with Didymosphenia's ability to colonize and persist in regulated rivers, where biofilm-disrupting spates are suppressed.

4. Greater understanding of the colonization dynamics of this species may help explain the geographical and habitat expansion of Didymosphenia and help model its potential range.

Acknowledgments Brad Taylor, Clancy Brown, and Bobbi Peckarsky provided helpful advice on field site locations and logistics. Emilee Tarver helped with field work, and Sarah Hobson and Russell Hobson assisted with laboratory work. Research funding was provided by the Oklahoma EPSCoR and NSF grant DEB-0447449 to EAB.

Open Access This article is distributed under the terms of the Creative Commons Attribution Noncommercial License which permits any noncommercial use, distribution, and reproduction in any medium, provided the original author(s) and source are credited.

\section{References}

Ács É, Kiss KT, Szabó K, Makk J (2000) Short-term colonization sequence of periphyton on glass slides in a large river (River Danube, near Budapest). Arch Hydrobiol Suppl 136:135-156

Barranguet C, Veuger B, van Beusekom SAM, Marvan P, Sinke JJ, Admiraal W (2005) Divergent composition of algal-bacterial biofilms developing under various external factors. Eur J Phycol 40:1-8. doi:10.1080/09670260400 009882 
Beltrami ME, Blanco S, Ciutti F, Cappelletti C, Monauni C, Pozzi S, Rimet F, Ector L (2008) Distribution and ecology of Didymosphaenia geminata (Lyngbye) M. Schmidt (Bacillariophyta) in Trentino watercourses (Northern Italy). Cryptogam, Algol 29:141-160

Bergey EA (2006) Measuring the surface roughness of stream stones. Hydrobiologia 563:247-252. doi:10.1007/s10750006-0016-4

Bergey EA (2008) Does rock chemistry affect periphyton accrual in streams? Hydrobiologia 614:141-150. doi: 10.1007/s10750-008-9450-9

Bergey EA, Getty GM (2006) A review of methods for measuring the surface area of stream substrates. Hydrobiologia 556:7-16. doi:10.1007/s10750-005-1042-3

Bhatt JP, Bhaskar A, Pandit MK (2008) Biology, distribution and ecology of Didymosphenia geminata (Lyngbye) Schnidt an abundant diatom from the Indian Himalayan rivers. Aquat Ecol 42:347-353. doi:10.1007/s10452-007-9106-2

Blinn DW, Fredericksen A, Korte V (1980) Colonization rates and community structure of diatoms on 3 different rock substrata in a lotic system. Br Phycol J 15:303-310. doi: 10.1080/00071618000650311

Branson J (2006) Didymosphenia geminata economic impact assessment. In: New Zealand Institute of Economic Research. Final Report for Biosecurity New Zealand. Available from http://www.biosecurity.govt.nz/pest-anddisease-response/pests-and-diseases-watchlist/didymospheniageminata/science-technical\#ecolo. Accessed 10 Sept 2008

Clifford HF, Casey RJ, Saffran KA (1992) Short-term colonization of rough and smooth tiles by benthic macroinvertebrates and algae (chlorophyll $a$ ) in two streams. J N Am Benthol Soc 11:304-315. doi:10.2307/1467650

Cooksey KE, Wigglesworth-Cooksey B (1995) Adhesion of bacteria and diatoms to surfaces in the sea: a review. Aquat Microb Ecol 9:87-96. doi:10.3354/ame009087

Dudley TL, D'Antonio CM (1991) The effects of surface texture, grazing, and disturbance on macroalgal establishment in streams. Ecology 72:297-309. doi:10.2307/1938923

Falciatore A, d'Alcalà MR, Croot P, Bowler C (2000) Perception of environmental signals by a marine diatom. Science 288:2363-2366. doi:10.1126/science.288.5475.2363

Gaskill DL, Mutschler FE, Kramer JH, Thomas JA, Zahony SG (1991) Geologic map of the Gothic Quadrangle, Gunnison County, Colorado. US Geological Survey. Quadrangle Map GQ-1689

Hoagland KD, Roemer SC, Rosowski JR (1982) Colonization and community structure of 2 periphyton assemblages, with emphasis on the diatoms (Bacillariophyceae). Am J Bot 69:188-213. doi:10.2307/2443006

Hudon C, Bourget E (1981) Initial colonization of artificial substrata: community development and structure studied by scanning electron microscopy. Can J Fish Aquat Sci 38:1371-1384. doi:10.1139/f81-184

Kawecka B, Sanecki J (2003) Didymosphenia geminata in running waters of southern Poland-symptoms of change in water quality? Hydrobiologia 495:193-201. doi:10.1023/ A: 1025469500265

Kilroy C (2004) A new alien diatom, Didymosphenia geminata (Lyngbye) Schmidt: its biology, distribution, effects and potential risks for New Zealand fresh waters. In: National Institute of Water and Atmospheric Research. Client Report: CHC2004-128. Christchurch, New Zealand. Available from http://www.biosecurity.govt.nz/pest-anddisease-response/pests-and-diseases-watchlist/didymos phenia-geminata/science-technical\#ecolo. Accessed 10 Sept 2008

Kilroy C, Biggs B, Blair N, Lambert P, Jarvie B, Dey K, Robinson K, Smale D (2005) Ecological studies on Didymosphenia geminata. In: National Institute of Water and Atmospheric Research. Client Report: CHC2005-123. Christchurch, New Zealand. Available at http://www.biosecurity.govt.nz/files/ pests/didymo/didymo-ecology-jan-06.pdf. Accessed 12 Dec 2008

Kilroy C, Snelder TH, Floerl O, Vieglais CC, Dey KL (2008) A rapid technique for assessing the suitability of areas for invasive species applied to New Zealand's rivers. Divers Distrib 14:262-272. doi:10.1111/j.1472-4642.2007.00406.x

Kirkwood AE, Shea T, Jackson LJ, McCauley E (2007) Didymosphenia geminata in two Alberta headwater rivers: an emerging invasive species that challenges conventional views on algal bloom development. Can J Fish Aquat Sci 64:1703-1709. doi:10.1139/F07-152

Korte VL, Blinn DW (1983) Diatom colonization on artificial substrata in pool and riffle zones studied by light and scanning electron microscopy. J Phycol 19:332-341. doi: 10.1111/j.0022-3646.1983.00332.x

Larned S, Arscott D, Blair N, Jarvie B, Jellyman D, Lister K, Schallenberg M, Sutherland S, Vopel K, Wilcock B (2007) Ecological studies of Didymosphenia geminata in New Zealand, 2006-2007. In: National Institute of Water and Atmospheric Research. Client Report: CHC2007-070. Christchurch, New Zealand. Available at http://www.bio security.govt.nz/files/pests/didymo/didymo-ecology-dec-07. pdf. Accessed 12 Dec 2008

Patil JA, Anil AC (2005) Biofilm diatom community structure: influence of temporal and substratum variability. Biofouling 21:189-206. doi:10.1080/08927010500256757

Peterson CG (1996) Mechanics of lotic microalgal colonization following space-clearing disturbances acting at different spatial scales. Oikos 77:417-435. doi:10.2307/3545932

Peterson CG, Stevenson RJ (1989) Substratum conditioning and diatom colonization in different current regimes. J Phycol 25:790-793. doi:10.1111/j.0022-3646.1989.00790.x

Sartory DP, Grobbelaar JU (1984) Extraction of chlorophyll $a$ from freshwater phytoplankton for spectrophotometric analysis. Hydrobiologia 114:177-187

Sekar R, Venugopalan VP, Satpathy KK, Nair KVK, Rao VNR (2004) Laboratory studies on adhesion of microalgae to hard surfaces. Hydrobiologia 512:109-116. doi:10.1023/ B:HYDR.0000020315.40349.38

Spaulding S, Elwell L (2007) Increase in nuisance blooms and geographic expansion of the freshwater diatom Didymosphenia geminata: Recommendations for response. In: White Paper. USEPA Region 8 and Federation of Fly Fishers. Available at http://www.epa.gov/Region8/water/didymos phenia/. Accessed 12 Dec 2008

Thompson SE, Taylor AR, Brownlee C, Callow ME, Callow JA (2008) The role of nitric oxide in diatom adhesion in 
relation to substratum properties. J Phycol 44:967-976. doi: 10.1111/j.1529-8817.2008.00531.x

Wetherbee R, Lind JL, Burke J, Quatrano RS (1998) The first kiss: establishment and control of initial adhesion by raphid diatoms. J Phycol 34:9-15. doi:10.1046/j.15298817.1998.340009.x
Wigglesworth-Cooksey B, Cooksey KE (1992) Can diatoms sense surfaces?: state of our knowledge. Biofouling 5:227-238. doi:10.1080/08927019209378243 